\title{
Realisme Moral dalam Pandangan Ṭabāțabā'ī (Respons terhadap Natuaralisme, Emotivisme, dan Anti-Realisme Moral)
}

\author{
Basrir Hamdani \\ Sekolah Tinggi Filsafat Islam (STFI) Sadra Jakarta \\ rierlucky@yahoo.com
}

\begin{abstract}
The main purpose of this article is to point out Tabātabā' '’s metaethical idea, that is moral realism, based on the principle of moral philosophy which found in his theory of I'tibāriyat, a theory of perception dealing with various kinds of perception related to practical action of human being whether individual or social. Departing from many problems related to ontological and epistemological statuses of morality that have not been solved yet by several modern metaethical theories, cognitivism and non-cognitivism, this Tabātabā' $\bar{\imath}$ 's metaethical idea is considered enable to give alternative solutions by proposing two points as the results of reflection on it that morality in the case of metaethical study is imaginative-cognitive-relative and existent in threefold components (action, pupose, and nature of an actor). The elaboration of this reflection in the same time constitutes a response to those modern metaethical theories especially Naturalism, Emotivism, and Anti-Realism. The method by which the writer presents this article is analytical-criticalcomparative method, that is, to analyze every idea or theory of metaethics mentioned and, then, by comparative-critical approach, the writer attempts to provide a response to some claims from Naturalism, Emotivism, and Anti-Realism.
\end{abstract}

Keywords: Moral Realism, Tabātabā'̄̄, Naturalism, Emotivism, Anti-Realism.

\begin{abstract}
Abstrak: Tujuan pokok dari tulisan ini adalah menunjukkan gagasan meta-etika Tabātabà'’̄, yaitu realisme moral, yang berpijak pada prinsip filsafat moral yang terdapat dalam teori I'tibāriyat, suatu teori persepsi yang mengupas jenis-jenis persepsi yang terkait dengan tindakan praktis manusia baik secara individual maupun sosial. Berangkat dari persoalan-persoalan yang belum terselesaikan terkait status ontologis dan epistemologis moral oleh beberapa teori meta-etika modern, kognitivisme dan non-kognitivisme, gagasan meta-etika Tabātabā' $\bar{\imath}$ ini dirasa mampu memberi solusi alternatif dengan mengajukan dua hal sebagai hasil refleksi bahwa moralitas dalam kajian meta-etika adalah imaginatif-kognitif-relatif dan Eksistensi dalam Tiga Serangkai Komponen (tindakan, tujuan, dan tabiat pelaku). Elaborasi atas refleksi ini sekaligus merupakan respons terhadap teori-teori meta-etika modern khususnya Naturalisme, Emotivisme, dan AntiRealisme. Metode yang penulis gunakan dalam menyajikan tulisan ini adalah analitis-kritiskomparatif, yaitu menganalisis setiap gagasan atau teori meta-etika yang telah disebutkan dan kemudian dengan pendekatan komparatif-kritis penulis berusaha memberi respons terhadap klaimklaim emotivisme dan naturalisme moral.
\end{abstract}

Kata Kunci: Realisme Moral, Tabātabā'̄̄, Naturalisme, Emotivisme, Anti-Realisme. 


\section{Pendahuluan}

Salah satu isu yang paling menyita perhatian ketika membincangkan tentang moral atau nilai suatu tindakan manusia adalah masalah dasar epistemologis dan ontologisnya; pengetahuan tentang nilai baik menyangkut konsepsi maupun justifikasi dan eksistensinya. Kedua masalah tersebut sangat saling terkait di mana, jika mengikuti tren filsafat modern, status epistemologis berkorelasi dengan status ontologisnya. Status ontologis nilai moral dipahami apakah terhubung dengan objek-objek faktual dan kongkret sehingga persepsi tentangnya harus diperlakukan seperti pengetahuan faktual tersebut ataukah tidak terkait sama sekali dengan realitas ekstra mental sehingga nilai moral hanyalah kreasi dan konstruksi mental, maka pengetahuan tentangnya adalah imajinasi, fiksi, atau subjektivitas?

Dalam kajian tentang nilai moral (value), kedua aspek ontologis dan epistemologis di atas dibahas dalam satu bidang khusus, yaitu apa yang disebut dengan 'meta-etika' (meta-ethics), satu bidang kajian menyangkut nilai suatu tindakan manusia dengan menelusuri seluk-beluknya secara filosofis, yaitu tinjauan ontologis dan epitemologis. ${ }^{1}$ Terkait hal ini, paling tidak ada tiga pandangan yang penulis dapat sebutkan di sini, yaitu: naturalisme, intuisionisme, dan non-kognitivisme. Pandangan yang pertama meyakini bahwa nilai moral dapat ditemukan pada objek-objek faktual baik dilihat secara empiris, meta-fisis, maupun teologis. Artinya nilai moral dapat didefinisikan sebagai fakta empiris atau meta-fisis yang dalam istilah para pendukung pandangan ini, "nilai sama dengan fakta" (value is defined in terms of fact). Misalnya, pernyataan 'jujur adalah baik'

${ }^{1}$ Adrew Fișer, Metaethics: An Introduction (UK: Acumen Publișing, 2011), 1. artinya 'jujur adalah objek yang dikehendaki' atau 'jujur adalah tindakan yang diharuskan oleh masyarakat' atau 'jujur adalah perintah Tuhan'. ${ }^{2}$ Pandangan ini mengukur aspek ontologis dan epistemologis nilai moral dengan objek-objek faktual lain yang dianggap sebagai landasan berpijaknya. ${ }^{3}$

Berbeda dengan Naturalisme, Intusionisme meyakini bahwa nilai moral memiliki eksistensi sendiri yaitu sebagai sifat yang melekat pada setiap tindakan itu sendiri, bukan sebagai sifat atau entitas aksidental bagi objek-objek faktual lainnya. Suatu tindakan 'menolong orang lain', misalnya, memiliki sifat 'baik' pada dirinya sendiri, bukan karena objek-objek lain di luar tindakan moral. Namun demikian nilai moral tersebut, menurut paham ini, hanya bisa diketahui makna dan kebenarannya melalui intuisi; tidak memerlukan justifikasi untuk membuktikan kebenarannya karena bersifat swabukti (self-evident). Proposisi-proposisi moral bersifat 'terang-benderang' kebenarannya atau, dalam istilah Descartes 'clearly and distinctively true.' ${ }^{4}$

Adapun non-Kognitivisme moral yang bersandar pada paradigma positivistik, yaitu Emotivisme, sebagaimana yang dipopulerkan oleh A. J. Ayer, meyakini bahwa nilai moral tidak memiliki pijakan ontologis atau tidak merepresentasikan realitas dan [pernyataan/ proposisi tentangnya] tidak berurusan dengan

${ }^{2}$ William K. Frankena, Ethics (USA: PrenticeHall International Inc., 1973), 97-98.

${ }^{3}$ Charles R. Pidgen, "Naturalism," dalam Peter Singer (eds), A Companion to Ethics (UK: Blackwell Publișer Ltd., 1993), 421-422.

4 Pandangan ini cukup populer dan diterima oleh banyak filsuf moral hingga saat ini, di antara filsuf-filsuf yang mendukungnya adalah Butler, Sidgwick, Rașdall, G.E. Moore, Prich Ard, Ross, Carritt, Hartmann, Ewing, dan bahkan kemungkinan Plato juga menganut pandangan ini. Lihat William K. Frankena, Ethics (USA: Prentice-Hall International Inc., 1973), 102. 
penilaian salah atau benar. ${ }^{5}$ Lebih jauh, menurut Ayer, nilai 'baik' dan 'buruk' hanyalah ekspresi dan emosi mental tanpa makna tak ubah suatu ungkapan kosong seperti 'booo' atau 'huuu' sehingga persepsi tentangnya hanyalah kreasi mental yang tidak dapat dijustifikasi secara rasional. Mengatakan 'tolong-menolong adalah baik', misalnya, sama saja dengan mengatakan 'tolong-menolong adalah booo' atau 'mencuri adalah buruk' sama dengan mengatakan 'mencuri adalah huuu'. Ungkapan-ungkapan tersebut dalam susunan kata hanyalah membentuk suatu kalimat esai (insyā'i), bukan proposisi (khabar) yang dapat dihukumi salah dan benar. ${ }^{6}$

Ketiga pandangan tentang nilai dan persepsi moral di atas sama-sama memiliki konsekuensi terhadap status ontologis dan epistemologis nilai moral. Pandangan pertama dan kedua mengafirmasi keberadaan nilai moral dan kemampuan mental menangkap konsep serta justifikasinya, meskipun keduanya berbeda dari segi cara mengetahui dan membuktikan kebenarannya. Adapun pandangan yang ketiga berada pada posisi menegasikan kedua aspek di atas; menolak keberadaan nilai moral dan menganggap mental tidak dapat mengonstruksi pengetahuan apa pun tentangnya selain menganggapnya sebagai ungkapan-ungkapan emosional atau perasaan sentimental semata.

Semua pandangan di atas memiliki kelemahan-kelemahan dan menuai banyak kritik. Pandangan pertama dan kedua meskipun mengafirmasi status ontologis nilai moral, namun dari segi epistemologis memberi ruang persoalan yang cukup serius.

5 Alexander Miller, An Introduction to Contemporary Metaethics (UK: Polity Press, 2003), 322.

\footnotetext{
${ }^{6}$ Frankena, Ethics, 105.
}

Pandangan pertama terkait masalah menakar konsepsi dan justifikasi nilai moral dengan sesuatu di luar moral itu sendiri. Sebagaimana kritik G. E. Moore bahwa naturalisme moral telah melakukan apa yang ia sebut sebagai kesalahan naturalistik (naturalistic fallacy) karena memahami konsep dan justifikasi nilai moral dengan sesuatu di luar moral itu sendiri (non ethical terms). ${ }^{7}$ Selain itu, menurut penulis, paham ini juga mengklaim nilai 'baik' dan 'buruk' sebagai sifat-sifat yang melekat secara esensial pada tindakan layaknya sifat-sifat seperti kualitas dan kuantitas objek-objek faktual, sehingga cara justifikasi kebenaran moral seperti menjustifikasi objek-objek faktual yang memiliki kebenaran objektif dan universal. Hal ini terlihat dari sikapnya yang menyamakan proposisi-proposisi moral dengan proposisi-proposisi faktual. Pandangan kedua juga tidak terbebas dari syak karena menjadikan nilai moral sebagai sifat sesuatu yang melekat secara esensial pada setiap tindakan dan hanya bisa diketahui secara intuitif yang mana sangat bersifat subjektif dan tidak memberikan ruang untuk dipahami secara bersama-sama serta dibuktikan kebenarannya oleh orang lain, sementara penyifatan 'baik' dan 'buruk' pada suatu tindakan, 'jujur adalah baik' atau 'tirani adalah buruk', misalnya, tidak bisa dipahami begitu saja dan butuh pembuktian atas kebenarannya. $^{8}$ Sedangkan paham ketiga dengan berpijak pada paradigma positivistik yang mengukur segala sesuatu baik ontologis dan epistemologis berdasarkan standar entitas faktual-kongkret layaknya benda-benda di alam ekstra-mental, telah menafikan nilai

${ }^{7}$ Frankena, Ethics, 99.

${ }^{8}$ M. Taqi Mișbaḥ Yazdī, Manhaj al-Jadīd fì Ta'līm al-Falsafah, Vol. I (Beirut: Dār al-Ta'aruf wa al-Mațbu'at, 1998), 248. 
moral itu sendiri; nilai 'baik' dan 'buruk' tidak lebih hanyalah perasaan sentimental terhadap sesuatu tanpa ada relasi apa pun dengan realitas.

Berdasarkan penjelasan di atas, ketiga pandangan tersebut menyisakan persoalan menyangkut kedua aspek dari nilai moral, sehingga, menurut penulis, masih sangat membutuhkan penjelasan dan analisis yang lebih komprehensif dan lebih proporsional. Dalam hal ini, penulis mencoba melakukan analisis terhadap satu pandangan tentang nilai moral yang diajukan oleh Ṭabāțabā' $\mathbf{1}$, seorang filsuf Muslim kontemporer, yang dianggap memiliki orisinalitas dalam gagasannya. Menurut penulis, pemikirannya tentang nilai moral bisa dianggap cukup komprehensif dan proporsional serta tidak tergesa-gesa dalam menyimpulkan. Tabātabā'̄̄ menelusuri realitas nilai moral dengan memulai dari aspek epistemologis sebagaimana tertuang dalam satu bab khusus yang ia namakan dengan bab 'I'tibāriyat', yaitu persepsi imaginatif.

Dalam persepsi I'tibāriyat, persepsi moral 'baik' dan 'buruk' merupakan salah satu di antaranya. Menurut Ṭabāṭabā'̄', persepsi moral bukanlah sifat esensial tindakan yang ditangkap mental secara langsung, melainkan suatu persepsi yang diciptakan mental untuk menyebut suatu tindakan, yaitu tindakan yang dapat mengantarkan pada kesempurnaan atau tidak bagi pelakunya. Jika tindakan tersebut membawa pelakunya pada kesempurnaan, maka tindakan tersebut akan disematkan padanya oleh mental sebagai 'baik', yaitu suatu sifat yang diciptakan mental berdasarkan tujuan esensial dari suatu tindakan. Sebaliknya, jika tidak mengantarkan maka, mental akan menyebutnya sebagai 'buruk', sehingga tindakan tersebut tidak harus dilakukan. ${ }^{9}$

Adapun nilai moral 'baik' dan 'buruk', menurut Ṭabātabā'̄ adalah sifat esensial yang melekat di antara tindakan dan efek yang dimunculkannya serta karakter subjek/pelaku tertentu (partikular), sehingga nilai moral tidak bersifat tetap dan universal bagi satu tindakan dan bagi seluruh pelaku. Ia sangat tergantung kepada tindakan dan karakter pelaku-pelakunya yang berbeda-beda. Tindakan 'belajar', misalnya, efeknya bisa berbeda-beda jika dihubungkan pada karakter setiap pelaku. Bagi si A mungkin efeknya akan mengantarkan kepada kesempurnaan si A berdasarkan karakternya, sehingga mental akan menyebut 'belajar' sebagai sebuah kebaikan. Namun di pihak lain, bagi si B, mungkin saja efeknya justru sebaliknya, tidak mengantarkan pada kesempurnaannya sesuai dengan karakter si B yang membuat mental akan menyebutnya sebagai sebuah keburukan. ${ }^{10}$

Sekilas gagasan Ṭabāṭabā'̄ di atas seperti mengafirmasi baik pandangan emotivisme maupun naturalisme, karena di satu sisi, menganggap konsep moral bukanlah konsep yang memiliki dasar ontologis dan merepresentasikan objek faktual sehingga proposisinya tidak bisa dihukum benar dan salah sebagaimana anggapan emotivisme, dan di lain sisi, mengatakan bahwa konsep moral memiliki relasi dengan karakter subjek sebagaimana klaim naturalisme. Namun demikian, jika dicermati secara seksama, pemikiran Ṭabāțabā'̄i di atas berbeda dan tidak mengafirmasi kedua pandangan

9 Muhammad Husein Ṭabāṭabā'̂̀, Majmü'at Rasā'il al-'Allāmah al-Ṭabātabā'̄o (Qom: Maktabah Fadak, 2007), 352.

${ }^{10}$ Ṭabāțabā'î, Majmu'at Rasā'il Al- 'Allamah AlTabātabā'̂̀, 352. 
tersebut. Meskipun Ṭabāṭabā'̄̄ menganggap bahwa nilai moral bukanlah sifat bagi objek faktual sebagai basis ontologisnya, namun ia tidak mengatakan bahwa nilai moral adalah sekedar perasaan emosional dan ilusi, melainkan nilai moral adalah entitas yang ada di antara tindakan, efek, dan karakter pelaku yang konsepnya (baik dan buruk) dipersepsi mental berdasarkan karakter setiap pelaku yang berbeda satu dengan yang lain. Begitu pula, meskipun Ṭabāțabā'̄̄, mengaitkan nilai moral dengan karakter subjek, namun ia tidak mengukur nilai moral dengan sesuatu di luar moral, melainkan tetap pada tindakan itu sendiri dengan melihat efeknya bagi pelaku. Selain itu, Ṭabātabā'̄̄ juga tidak melihat nilai moral sebagai sesuatu yang memiliki muatan objektif sebagaimana klaim naturalisme, melainkan bermuatan relatif yang berbedabeda bagi setiap individu.

Akhirnya, berangkat dari uraian di atas, tulisan ini berusaha menganalisis pandangan meta-etika Ṭabāṭabā'̄ untuk merespons kedua pandangan meta-etika moral, emotivisme yang bersifat anti-realis dan naturalisme moral. Adapun metode yang penulis gunakan adalah analisis-komparatif, yaitu menganalisis setiap gagasan dan kemudian dengan pendekatan komparatif penulis berusaha memberi respons terhadap klaim-klaim emotivisme dan naturalisme moral.

\section{Meta-etika dan Ragam Teorinya}

Dalam filsafat moral, pembahasan tentang moralitas dibedakan dalam tiga sudut pandang, yaitu nilai suatu tindakan tertentu, prinsip dan faktor yang menentukan nilai tersebut, dan status ontologis serta epistemologis nilai. Ketiga sudut pandang tersebut, selanjutnya, menjadi basis pembagian filsafat moral menjadi tiga bagian; secara berurutan, yang pertama disebut dengan Etika Terapan (Applied Ethics), yaitu kajian filosofis moral yang menekankan pada pembahasan tentang nilai tindakan tertentu, misalnya apakah tindakan aborsi itu baik atau buruk, berlaku adil adalah baik, dan lain sebagainya. Yang kedua, dikenal dengan istilah Etika Normatif (Normative Ethics), yaitu penyelidikan terhadap prinsip-prinsip nilai yang melandasi moralitas dan faktorfaktor yang menentukan keputusan moral, misalnya menjelaskan apa yang dimaksud tindakan baik atau buruk? Mengapa harus berbuat baik dan menghindari tindakan yang buruk? dan lain sebagainya. Sedangkan yang ketiga, disebut dengan istilah Meta-Etika (Meta-Ethics), yaitu tinjauan filosofis moral yang berusaha menyelidiki persoalanpersoalan terkait eksistensi nilai moral dan justifikasi keputusan-keputusan moral.

Andrew Fisher menganalogikan ketiga bagian filsafat moral tersebut dengan unsurunsur dalam sepak bola, di mana para pemain yang bermain sepak bola dapat diasumsikan sebagai para pelaku langsung tindakan tertentu moral atau sebagai applied ethicists. Hal ini mengingat yang lebih ditelisik adalah sisi praktis dalam menentukan nilai moral suatu tindakan tertentu, misalnya bagaimana seseorang harus berjalan, berbicara, bekerja sama dengan orang lain, dan lain sebagainya dalam bertindak yang baik dan benar. Adapun wasit dan hakim garis yang adalah para pengatur jalannya permainan dapat dianggap sebagai yang memperhatikan prinsip-prinsip yang mendasari tindakan moral atau sebagai normative ethicists. Ini tidak berlebihan karena, sebagaimana penjelasan di atas, dalam etika normatif hal yang disoroti adalah investigasi tentang makna nilai-nilai moral dan rasionalisasi terhadap setiap tindakan moral; apa yang dimaksud dengan 'baik' atau 'buruk' pada suatu tindakan tertentu dan apa 
standar nilai-nilai moral tersebut? Sedangkan analis dan komentator yang adalah orangorang yang tidak bermain dan mengatur permainan, melainkan menganalisis jalannya pertandingan dan apa yang terjadi di dalamnya dapat disebut sebagai yang menganalisis status epistemologis yang meliputi aspek logis pernyataan moral (moral language) dan psikologi moral (moral psychology), ${ }^{11}$ dan status ontologis moral atau disebut sebagai meta-ethicists. ${ }^{12}$ Selaras dengan apa yang ditegaskan oleh Frankena bahwa meta-etika menyelidiki persoalanpersoalan seperti makna atau kegunaan dari ekspresi 'baik' atau 'buruk', justifikasi terhadap keputusan-keputusan moral; apakah memungkinkan untuk melakukan justifikasi terhadap nilai moral? Perbedaan antara moral dan non-moral, dan lain sebagainya. ${ }^{13}$ Berdasarkan tema yang diangkat, tulisan ini tidak akan membahas lebih jauh Etika Terapan dan Etika Normatif, melainkan hanya fokus pada eksposisi ringkas Meta-Etika.

Berdasarkan fokus bahasan meta-etika pada status epistemologis dan ontologis di atas, terdapat beragam pandangan atau teori meta-etika. Pada bahasan status epistemologis, beragam teori meta-etika terangkum secara garis besar, mengadopsi klasifikasi yang dibuat oleh Frankena, dalam tiga tipe, yaitu definis, intuisionisme atau nonnaturalisme, dan non-kognitif atau non-

${ }^{11}$ Disebut dengan istilah psikologi moral (moral psychology) karena metaetika mengivestigasi ihwal pikiran subjek apakah ketika ia membuat keputusankeputusan moral, keputusan-keputusan tersebut mengekspresikan sebuah keyakinan (belief) atau nafsu (emosi) belaka? Lihat Fișer, Metaethics: An Introduction, 3.

${ }^{12}$ Fișer, Metaethics: An Introduction, 1-2.

13 Frankena, Ethics, 5. Lihat juga James W. Gray, A Free Introduction to Moral Philosophy (2010), 7. deskriptif. ${ }^{14}$ Sedangkan pada bahasan status ontologis, pandangan-pandangan meta-etika terpulang pada dua aliran besar, yaitu realisme dan anti-realisme moral. Berikut pemaparan ragam teori dan gagasan metaetika tersebut di atas secara ringkas.

\section{Teori Definis}

Berangkat dari keyakinan bahwa moralitas atau nilai moral dapat dijustifikasi 'benar' dan 'salah' sebagaimana nilai realitas faktual, oleh para filsuf moral hal ini disebut dengan istilah kognitivisme moral. ${ }^{15}$ Secara garis besar kognitivisme memiliki dua bentuk, yaitu a). Justifikasi nilai moral mengikuti justifikasi benda-benda faktual yang dapat diukur dan ditentukan. Bentuk ini disebut dengan teori definis (definist theory of moral), yaitu teori meta-etika yang menganggap bahwa nilai moral dijustifikasi secara objektif dan ditarik akarnya pada hal-hal yang bersifat faktual. Dengan kata lain, nilai moral dapat didefinisikan dengan objek-objek faktual atau value in terms of facts. ${ }^{16}$ Misalnya, ketika dikatakan bahwa 'membunuh adalah tindakan yang buruk', maka nilai buruk pada tindakan membunuh dapat didefinisikan dengan sesuatu yang bersifat faktual di luar tindakan itu sendiri, yaitu 'sesuatu yang tidak diinginkan' atau 'kesepakatan masyarakat menuntut untuk tidak dilakukan' atau 'karena dilarang oleh Tuhan'. Salah satu filsuf yang mendukung gagasan ini adalah R. B. Perry. Ia mengajukan bentuk-bentuk definisi terhadap nilai moral: "good" means "being an object of favorable interest (desire)" ("baik" artinya "suatu objek keinginan (hasrat) yang menguntungkan) dan "right" means "being conducive to harmonious happiness" ("baik"

${ }^{14}$ Frankena, Ethics, 96.

15 Miller, An Introduction to Contemporary Metaethics, 3.

${ }^{16}$ Frankena, Ethics, 97. 
artinya "mendatangkan kebahagiaan harmonis"). ${ }^{17}$ Pandangan seperti yang diajukan oleh Perry inilah, menurut Frankena, disebut sebagai Naturalisme moral atau Etika Naturalis, sedangkan yang mengembalikan hukum moral pada kesepakatan sosial atau kepada agama dinamakan sebagai Moral Meta-fisis. ${ }^{18}$

\section{Intuisionisme atau Non-Naturalisme}

Kognitivisme tidak saja menekankan pada kemungkinan justifikasi moral dengan sesuatu yang bersifat faktual, tetapi juga kemungkinan justifikasi tersebut dikembalikan kepada hal yang bersifat nonfaktual, yaitu kepada nilai-nilai objektif moral itu sendiri, namun tidak dalam kerangka persepsi konseptual-inferensial akal, melainkan pemahaman mental secara intuitif atau kejernihan naluri. Nilai 'baik' atau 'buruk' pada suatu tindakan bersifat esensial dan niscaya, hanya saja tidak dapat dipahami atau dicerap secara konsepsi mental, melainkan secara intuitif mental. Melalui kejernihan hati dalam sebuah prosesi kontemplasi akan dapat mengantarkan pada pengetahuan tentang fakta-fakta moral secara jelas dan nyata tanpa memerlukan pembuktian secara konseptual dan di realitas eksternal.

Paham ini dikembangkan oleh para filsuf moral seperti Moore, Ross, Rashdal, dan lain-lain. Menurut Ross, kita dapat mengetahui fakta-fakta moral melalui intuisi dan pengetahuan tersebut bersifat jelas pada dirinya tanpa memerlukan pembuktian atau self-evident, artinya, dengan kejernihan hati dalam proses kontemplasi terhadap tindakantindakan moral, kita dapat mengetahui secara intuitif bahwa proposisi 'berkata jujur adalah

17 Perry R. B., Realms of Value (Cambridge: Harvard University Press, 1954), 3.

${ }^{18}$ Frankena, Ethics, 98. baik' adalah benar berdasarkan kontemplasi yang kita lakukan. Pengetahuan intuitif moral, Ross menegaskan, seperti pengetahuan aksiomatis matematika yang tunduk pada hukum kontradiksi atau tidak mungkin benar dan salah di waktu yang sama. Keputusan matematis yang self-evident 'benar' seperti '2 $+2=4$ ' tidak mungkin juga 'salah' di saat yang sama, tidak berbeda dengan proposisiproposisi moral seperti contoh di atas 'jujur adalah baik' adalah benar secara self-evident dan juga salah di saat bersamaan. ${ }^{19}$ Pandangan seperti yang diajukan oleh Ross inilah yang disebut dengan intuisionisme moral yang merupakan bentuk lain dari Kognitivisme namun berbeda dengan Naturalisme.

3. Non-Kognitif atau Non-Deskriptif

Kebalikan dari Kognitivisme adalah non-Kognitivisme atau non-Deskriptivisme yang menolak bahwa nilai-nilai moral dapat dihukumi benar atau salah. Aliran ini berkeyakinan bahwa nilai moral tidak memiliki basis yang objektif di realitas eksternal sehingga mental mampu menghukuminya sebagai benar atau salah. Proposisi-proposisi yang terbentuk darinya tidak ubah seperti ungkapan-ungkapan ilusif tanpa makna. Proposisi moral hanyalah keputusan psikis atau emosi, ia hanya berupa ekspresi dari luapan emosi seseoarang bukan mengekspresikan sebuah keyakinan/kepastian (epistemik). ${ }^{20}$ Oleh sebab itu, aliran ini dikenal pula dengan emotivisme sebagaimana dikembangkan oleh seorang Positivis, A. J. Ayer, sebagai tokoh utamanya.

4. Realisme dan Anti-Realisme Moral

Realisme moral yang lebih menekankan pada aspek ontologi moral secara otomatis

${ }^{19}$ Gray, A Free Introduction to Moral, 99.

20 Miller, An Introduction to Contemporary Metaethics, 6-7. 
adalah Kognitivisme moral pada aspek epistemologinya, namun tidak semua paham yang dikategorikan sebagai Kognitivisme adalah otomatis realis, melainkan sebagian paham menganut bentuk anti-realisme moral. Hal ini ditengarai oleh reduksi yang terjadi pada makna realitas atau sesuatu yang nyata ada (real existent/thing) dan tidak tergantung pada proyeksi mental (mind independent reality) kepada hal-hal yang bersifat material atau natural (alamiah) sebagai sesuatu yang riil. Oleh sebab itu, sesuatu yang berada di luar area material dan natural secara otomatis akan disebut sebagai tidak riil. Berdasarkan hal ini dapat disimpulkan bahwa, tidak saja paham non-Kognitivisme tetapi juga pahampaham Kognitivisme non-Naturalis akan digolongkan sebagai anti-Realisme moral, yaitu paham yang meyakini bahwa moral adalah fakta riil yang tidak tergantung pada proyeksi mental (mind-independent reality) namun hanya sebatas fakta-fakta material dan natural. ${ }^{21}$

\section{Teori I'tibāriyat sebagai Landasan Meta- Etika Tabātabā'̄}

Muhammad Husein Țabāṭabā'̄̄ (lahir pada tahun 1321 H/1904 M di kota Tabriz, Iran dan wafat pada tahun 1398 H/1981 M di kota Qum, Iran) adalah seorang filsuf Muslim terkemuka di era kontemporer yang pemikiran dan karya-karya filosofisnya - di antara yang utama antara lain: Bidāyat dan Nihāyat alHikmah, Ușūl al-Falsafah, Majmu' Rasā'il, dan lain-lain - banyak menjadi rujukan bagi para intelektual dan filsuf lain baik yang sezaman dengannya seperti Ruhullah Imam Khomeini maupun yang hidup di era setelahnya seperti Murtadhā Muthahhari, Muḥammad Taqi Miṣbaḥ Yazdi, Hasan Zādeh

\footnotetext{
${ }^{21}$ Fisher, Metaethics: An Introduction, 55.
}

Āmūli, dan lain-lain. Secara umum, corak filsafat Tabāțabā'̄ merupakan pengembangan dari filsafat 'Hikmah Muta'āliyah' yang digagas oleh Mullā Șadrā, namun tidak sedikit inovasi dan modifikasi darinya sehingga Hikmah Muta'āliyah bernuansa khas pemikirannya. Beberapa inovasi Ṭabātabā'̄̄ antara lain menyangkut isu-isu sebagai berikut: Burhān Limmī, Nafs al-Amr, Wujūd Rābiț, Burhān Shiddiqīn, Kembalinya ilmu Huṣūlī (konseptual) kepada ilmu Hudūrī (presentasional/kehadiran), Filsafat Moral atau Etika dan lain-lain, yang semua isu tersebut, kecuali Filsafat Moral, tidak dapat penulis paparkan satu persatu dalam artikel ini. $^{22}$

Berkenaan dengan filsafat moral yang menjadi fokus dari tulisan ini, pemikiran Ṭabātabā'̄ dianggap oleh sebagian kalangan pemikir dan filsuf, terutama oleh muridmuridnya seperti Muṭahhari dan Taqi Miṣbāh Yazdī, ${ }^{23}$ sebagai temuan dan sumbangsih orisinal darinya bagi perkembangan diskursus tentang filsafat moral, khususnya meta-etika, yang dituangkan dalam gagasan besar tentang persepsi-persepsi I'tibāriyat dengan makna khusus di dalam satu bab tersendiri baik dalam kitab Ușūl al-Falsafah maupun kitab Majmū' Rasā'il. Melalui pembahasan tentang persepsi I'tibari dengan makna khusus, Ṭabātabā'̄ memaparkan pandangannya tentang meta-etika, yaitu status ontologis dan epistemologis nilai-nilai moral, dalam sub bab khusus "baik dan buruk" (al-ḥusn wa al$q u b h)$.

22 Hasan Mu'allimi, Dkk., Tārīkh Falsafeh Islāmī (Qom: Markaz Jahānī 'Ulūm Islāmī, 1385), 319327.

23 Muțahhari menyebutkan hal ini dalam komentarnya terhadap kitab Ușūl al-Falsafah, sedangkan Taqi Miṣbạ̣ Yazdī menyebutkannya dalam kitab Risālat al-Tasyayyu' fi al- 'Ālam al-Mu'āṣir. 
Ṭabāṭabā'̄ memecahkan persoalan tentang nilai-nilai moral dengan berangkat dari diskursus persepsi (idrāk). Ia menelusuri seluk-beluk pengetahuan manusia dengan memisahkan persepsi yang terikat oleh objekobjek faktual, baik berupa persepsi langsung maupun tidak langsung dari abstraksi mental, yang ia sebut sebagai persepsi-persepsi faktual (al-idrākāt al-haqīqiyah), yaitu persepsi-persepsi yang merepresentasikan objek-objek faktual, baik langsung berupa persepsi inderawi (idrāk hissī) dan konsepkonsep inteleksi (mafhūm mahuwiyah) ma'qūlāt awwaliyah) maupun tak langsung berupa konsep-konsep logis dan filosofis (mafhūm manțiqū dan falsafī/ma'qulāt tsanawiyah). ${ }^{24}$ Persepsi-persepsi tersebut diperoleh mental baik melalui proses pengindraan maupun proses abstraksi melalui analisis akal atau intelek dari objek-objek faktual di alam eksternal. Lebih lanjut, Tabātabā'̄ menegaskan bahwa persepsipersepsi jenis ini dari segi konsepsi (tașawwur) mengacu pada suatu makna kongkret dan dari segi justifikasi (tașdīq) dapat diterapkan dalam argumentasi logis atau kaidah-kaidah logika, karena susunan kalimat yang terbentuk dari persepsi jenis ini adalah kalimat berita (khabar) atau pernyataan (proposisi/qadhiyah). Dalam kitab Ușūl alFalsafah, ia mengungkapkan:

Persepsi-persepsi faktual merupakan persepsi yang terefleksi di mental dan mengacu kepada realitas (eksternal) dan nafs $a l$-amr. ${ }^{25}$... dan memungkinkan

24 Ṭabātabā'̂̂, Nihāyat Al-Hikmah (Qom: Mu'assese-i Ȧ̀muzesy-i va Phezuhesy-i Imām Khumeini, $1390 \mathrm{H}), 275$.

${ }^{25}$ Nafs al-Amr merupakan alasan bagi wujud atau tsubūt yang bersifat asumtif bagi subjek berupa objek-objek yang tidak ditemukan di realitas eksternal atau mental. Dengan kata lain, ia adalah realitas yang diperluas yang menjadi lokus bagi persepsi yang menerapkannya dalam argumentasiargumentasi filosofis atau ilmiah [ilmu alam atau matematika], sehingga dapat menghasilkan kesimpulan yang ilmiah ataupun filosofis. ${ }^{26}$

Adapun persepsi-persepsi I'tibāriyāt, menurut Ṭabātabā'̄i, adalah pengetahuan yang tidak terikat oleh objek-objek faktual dan tidak terefleksi darinya, melainkan persepsi yang diperoleh mental dari upaya kreatifnya tanpa diawali oleh proses abstraksi dari objek faktual dan bukan berupa representasi darinya. Oleh sebab itu, persepsi jenis ini dari segi konsepsi tidak mengacu kepada suatu makna atau realitas tertentu di alam eksternal, sehingga tidak memiliki definisi, dan dari segi justifikasi tidak dapat diterapkan dalam argumentasi logis, filosofis atau ilmiah sebagaimana persepsi-persepsi faktual. Namun demikian, persepsi ini bukan pengetahuan fiktif dan ilusif, melainkan persepsi yang berhubungan dengan tindakan manusia dan dikreasi berkenaan dengan kebutuhan hidupnya. Selain itu, meskipun tidak merefleksikan secara langsung objekobjek faktual, persepsi jenis ini tetap memiliki relasi dengan realitas faktual di alam ekstramental. Țabāṭabā'̄i menerangkan bahwa:

Adapun persepsi-persepsi I'tibāriyāt merupakan kreasi murni mental manusia berkenaan dengan kebutuhan hidupnya. Persepsi jenis ini adalah rekaan, konsiderasi, dan upaya kreatif mental, tidak memiliki relasi [reflektif] dengan realitas eksternal (objek faktual) dan nafs al-amr. Persepsi-persepsi

objeknya tidak ditemukan di realitas eksternal dan mental. Lihat Basrir Hamdani, Modus Realisme Berdasarkan Teori Persepsi I'tibāriyat Tabātabā' $\overline{\text {, }}$ (Disertasi Program Doktoral Jami'at al-Mustafa-Iran yang telah disidangkan pada tanggal 29 Maret 2016), 75.

${ }^{26}$ Ṭabāṭabā'̂̀, Nihāyat al-Hikmah, 485. 
I'tibāriyat tidak memiliki nilai [asensi] logis (tidak dapat diterapkan dalam justifikasi dengan argumentasi logis, pen.). ${ }^{27}$

Poin paling penting yang menjadi batas pembeda bagi persepsi I'tibāriyat baik dengan persepsi faktual maupun dengan persepsi fiktif atau ilusif adalah relasinya dengan tindakan-tindakan manusia. Tindakan seolah menjadi objek tidak langsung dari persepsi ini, karena atas dasar tindakan dan tujuannya dalam rangka memenuhi kebutuhankebutuhan hidup manusia, mental menciptakan persepsi-persepsi ini. Oleh sebab itu, dalam penjelasan berikutnya, Tabāṭabā'̄ menamakan jenis persepsi I'tibāriyat dengan makna khusus sebagai persepsi praktis atau (al-I'tibāriyat al- 'Amaliyah). ${ }^{28}$

Dalam proses konsepsinya, sebagaimana telah disebutkan, persepsi I'tibāriyat tidak berpangkal dari objek faktual, namun tetap memiliki relasi dengan objek faktual dan konsepnya sebagai bahan bagi mental mereplika sebagian persepsi I'tibāriyat dengan daya imajinasi (tawahhum) untuk digunakan oleh mental menyebut suatu nilai yang berhubungan dengan tindakan, misalnya konsep "ri'asat" (kepemimpinan), "rā'is" (pemimpin), dan “mar'ūs" (yang dipimpin) yang direplika dari konsep " $r a$ 's" (kepala) yang dalam makna aslinya adalah anggota badan yang tertinggi yang berfungsi sebagai komandan dalam mengatur anggotaanggota badan lainnya. Țabāțabā' $\overline{1}$ menyebut proses replika tersebut dengan istilah isti'ārat (metafora), sebagaimana isti'ārat dalam terminologi bahasa dan sastra untuk menunjuk makna yang bukan makna aslinya.

\footnotetext{
27 Ṭabāțabā'̂̂, Nihāyat Al-Hikmah, 485.

28 Ṭabātabā'̂̂, Ușūl-i Falsafeh va Ravishe Ri'ālism, 568.
}

Pada sebagian persepsi I'tibāriyat lainnya, menurut Ṭabāṭabā'̄̄, mental menciptakannya melalui proses imaginatif dengan mempertimbangkan suatu tindakan dan segala yang terkait dengannya seperti tujuan dan kebutuhan hidup subjeknya untuk selanjutnya disifatkan dengan persepsi tersebut. Konsep 'baik' dan 'buruk', 'memilih yang lebih mudah', dan lain sebagainya, diciptakan mental secara imaginatif (I'tibārī) dengan mempertimbangkan suatu tindakan 'belajar', misalnya, dan melihat tujuan dan kebutuhan pelakunya. Jika tindakan tersebut sesuai dengan tujuan dan kebutuhan hidup yang dapat mendatangkan kesempurnaan bagi pelaku, maka mental akan menyifatinya dengan konsep 'baik' dan begitu juga sebaliknya, jika tidak sesuai, maka mental akan menyifatinya dengan konsep 'buruk' .

Jadi, dari segi konsep, persepsi I'tibāriyat tentunya tidak seperti persepsi faktual yang dicerap baik langsung maupun tidak langsung, dan merupakan refleksi dari objek-objek faktual. Persepsi I'tibāriyat merupakan kreasi mental murni yang tidak dicerap dari objek faktual dan merupakan refleksi darinya. Namun begitu, bukan berarti persepsi I'tibāriyat dalam proses konsepsinya terlepas sama sekali dari fakta-fakta eksternal, melainkan tetap terkait meskipun hanya sebatas bahan pertimbangan mental untuk menciptakan konsep dan selanjutnya menyifatinya secara metaforis. Fakta-fakta yang menjadi pertimbangan dan objek penyifatan metaforis mental tersebut, tidak lain adalah tindakan-tindakan bukan bendabenda kongkret.

Berdasarkan penjelasan di atas, maka berkenaan dengan moralitas atau nilai-nilai moral, boleh dan tidak boleh, baik dan buruk, dapat ditegaskan bahwa Tabātabā' meyakininya bukan sebagai sesuatu yang 
faktual, bukan pula sebagai sifat esensial ( $d z \bar{a} t \bar{\imath})$ dan niscaya ( eksternal termasuk tindakan, karena jika demikian maka setiap tindakan bernilai tetap dan tidak mungkin berbeda-beda bagi setiap subjeknya. Jika tindakan 'belajar' nilainya adalah baik dan bersifat esensial, maka tidak mungkin bernilai kebalikannya bagi subjek yang berbeda, namun pada kenyataannya 'belajar' tidak selalu baik bagi semua orang, bagi orang yang tidak memerlukannya, belajar adalah kesia-siaan dan tidak berdampak positif baginya. Lebih jauh, menurut Ṭabātabā'̄', nilai moral adalah sifat yang dilekatkan secara nisbi atau relatif dan imaginatif, bukan esensial atau niscaya, bagi subjek tertentu terhadap tindakan, tujuan, dan kebutuhannya. Nilai 'baik' dan 'buruk', sebagaimana telah dijelaskan sekilas, secara konsepsinya diciptakan oleh mental secara imaginatif sebagai sebuah persepsi untuk menyifatkan suatu tindakan yang memiliki kesesuaian (mulā'amah) atau tidak (ghair mulā'amah) dengan tujuan dan kebutuhan hidup subjek tertentu. Nilai tersebut tidak dicerap secara langsung dan niscaya ( darūrī) dari suatu tindakan, melainkan dipersepsi secara imaginatif dari tindakan ketika dikaitkan dengan tujuan dan kebutuhan subjek; apakah tindakan tersebut dapat mengantarkan kepada kesempurnaan atau tidak baginya. Dalam kitab Majmù' Rasā'il, Ṭabātabā'ī menegaskan bahwa:

Kebaikan suatu tindakan [belajar, misalnya] tidak lain karena selaras dengan fitrah suatu kaum berdasarkan tradisi ('adat) yang familier di tengahtengah mereka, sehingga mereka cenderung terhadapnya karena diyakini (melakukannya) merupakan kesempurnaan bagi mereka. Kebaikan pada tindakan tersebut tidak bersifat esensial (baik pada diri tindakan itu sendiri, pen.), karena jika kita tidak melihat kebaikan itu terletak pada 'keselarasan' dengan tabiat mereka, (melainkan pada perbuatan sebagaimana perbuatan, pen.) maka niscaya tindakan tersebut bernilai baik pula bagi kaum lain meskipun mereka tidak menganggapnya baik. Tidak pula kebaikan tindakan tersebut karena keselarasan dengan tabiat dari segi bahwa kebaikan adalah sifat bagi jiwajiwa manusia sehingga berlaku seperti rasa lezat dan sakit, melainkan kebaikan adalah sifat yang dipersepsi secara imaginatif berdasarkan tindakan. Tidak ada tindakan yang baik secara esensial dan niscaya, karena jika demikian maka tidak mungkin [bagi semua tindakan] tidak bernilai baik, melainkan 'baik' secara niscaya imaginatif (baik secara niscaya karena selaras dengan tabiat). ${ }^{29}$

Nilai moral tidak terdapat pada tindakan sebagai sebuah sifat esensial dan niscaya darinya sehingga memungkinkan mental untuk memersepsinya secara langsung dan konsep 'baik' atau 'buruk' dapat dikategorikan sebagai persepsi faktual serta dapat dijustifikasi secara faktual pula dengan argumentasi logis. Akan tetapi nilai moral merupakan sifat dari suatu tindakan ketika dikaitkan dengan tujuan, kebutuhan, dan tabiat subjek dalam bingkai keselarasan atau tidak, sehingga darinyalah mental secara imaginatif menciptakan konsep 'baik' dan 'buruk' bagi suatu tindakan. Dan dari ketentuan 'keselarasan atau tidak' justifikasi nilai moral dapat dilakukan; akan benar

${ }^{29}$ Țabāțabā'̄i, Majmū'at Rasā'il al- 'Allamah alTabātabā'i, 352. 
bernilai baik jika memenuhi syarat selaras dan tidak benar jika sebaliknya.

\section{Respons terhadap Naturalisme dan Emotivisme (Anti-Realisme) Moral}

Berdasarkan elaborasi tentang pandangan moralnya yang berangkat dari analisis isu persepsi di atas, gagasan metaetika (filsafat moral) Ṭabātabā'̄̄ memiliki posisi tersendiri di antara paham-paham metaetika lainnya seperti kognitivisme, khususnya naturalisme, non-kognitivisme dengan paham emotivismenya, dan relativisme. Meta-etika Tabātabā'̄ dapat pula dijadikan alternatif sudut pandang di tengah-tengah problematika moralitas yang masih aktual diperbincangkan.

Keunikan pandangan meta-etika Tabātabā'̄ dari segi epistemologis dan ontologis berdasarkan teori I'tibāriyat dapat ditemukan, paling tidak, pada dua hal, yaitu prinsip imaginatif-relatif-kognitif moral dan prinsip eksistensi moral dalam tiga rangkaian komponen. Berikutnya, pemaparan kedua prinsip ini penulis jadikan sekaligus sebagai respons terhadap paham-paham meta-etika modern, khususnya naturalisme moral dan emotivisme moral. Berikut ini penjelasannya:

1. Epistemologi Moral: Imaginatif-RelatifKognitif

Polemik seputar moralitas pada ranah meta-etika terpulang pada penelusuran secara epistemologis. Keputusan justifikasi moral baik kognitivisme dan non-kognitivisme bersinggungan pada anggapan bahwa nilai moral tidak dapat dipersepsi atau dicerap secara langsung dari suatu tindakan. Kedua paham di atas menganggap bahwa suatu tindakan bersifat netral. Nilai moral dikonsepsi dari hal-hal di luar tindakan (non moral instrumen), misalnya keinginan individu, kesepakatan sosial, dan perintah agama, sebagaimana yang diyakini kaum naturalis, adalah sumber-sumber perseptual bagi konsep moral. Berbeda dengan kognitivisme, non kognitivisme seperti emotivisme meyakini selain tindakan adalah netral, tetapi juga tidak ada nilai apa pun pada apa yang disebut dengan konsep moral. Pada titik ini pun bahwa suatu tindakan adalah netral, berdasarkan penjelasan sub bab sebelumnya, gagasan meta-etika Ţabāṭabā'̄ memiliki kesamaan dengan kedua paham di atas. Namun demikian, titik perbedaannya terletak pada anggapan Tabātabā'̄ bahwa konsep moral bersifat imaginatif (persepsi I'tibārī).

Konsep moral tidak bersumber dari fakta non moral dan tidak pula tidak bernilai atau tidak bermakna, melainkan dicerap oleh mental dari upaya imaginatif-kreatifnya yang tetap berpijak pada tindakan itu sendiri, tujuan, dan karakter/tabiat (tabi'at) setiap individu yang berkaitan dengan kebutuhan hidupnya. Ketiga rangkaian unsur tersebut, tentu, bukanlah sesuatu di luar moral, tetapi bukan pula sumber langsung dari konsep moral. Nilai 'baik' dan 'buruk' adalah konsep imaginatif mental yang disifatkan kepada suatu tindakan dengan mempertimbangkan unsur-unsur lain, yaitu tujuan dan karakter individu. Konsep moral tidak secara langsung dicerap dari tiga serangkai unsur tersebut, akan tetapi ketiga rangkaian unsur tersebut adalah objek pertimbangan bagi mental untuk menyifatkan suatu konsep moral. Dari tiga serangkai unsur tersebut mental mencerap secara langsung konsep keutamaan yang membuat suatu tindakan harus atau tidak harus/boleh dilakukan. Dari konsep keutamaan dan konsep 'harus' (al-wujūb al'am), yang juga persepsi imaginatif (I'tibārī) mental menyifatkan persepsi imaginatif 'baik' atau 'buruk' jika, sebaliknya, dari suatu 
tindakan mental mencerap 'tidak mendatangkan keutamaan' dan 'tidak harus' dilakukan. Tabāțabā'̄ menegaskan: “Maka jelaslah bahwa kebaikan mutlak pada tindakan memiliki bentuk relasi, yaitu relasi keniscayaan atau keutamaan (awla), dan [konsep] 'baik' adalah konsep imaginatif (I'tibārī). Demikian pula halnya pada keburukan. "30

Keutamaan (awlawiyah) pada suatu tindakan moral yang menjadi penentu bagi subjek atau pelaku untuk harus melakukan atau tidak harus (yanbaghi aw là yanbaghi) melakukannya, menurut Tabātabā'̄̄, terletak pada efek yang ditimbulkan oleh tindakan tersebut, yaitu dapat mengantarkan subjek pada kesempurnaannya atau fitrahnya sebagai manusia. Ia menyatakan bahwa:

([konsep] 'harus' dan 'tidak harus' melakukan suatu tindakan) merupakan konsep imaginatif (I'tibārī) pertama yang dicerap fitrah (jiwa) manusia untuk mengantarkannya kepada keutamaan secara esensial dan kesempurnaan mutlak nan hakiki ... ${ }^{31}$

Hal ini mempertegas dalam etika normatif bahwa Tabāṭabā'̄ termasuk filsuf yang menganut paham etika keutamaan atau virtue ethics sebagaimana mayoritas filsuf pendahulunya seperti Alfarabi dan Ibnu Sina.

Berbanding lurus dengan perbedaan pandangan menyangkut konsep moral di atas dengan paham kognitivisme dan nonkognitivisme, maka gagasan Țabātabā'̄ dalam hal justifikasi kebenaran nilai moral pun memiliki perbedaan yang cukup tegas. Jika kognitivisme memperlakukan proposisi moral seperti proposisi faktual namun mengukur

${ }^{30}$ Ṭabāṭabā'̂̀, Majmu'at Rasā'il Al- 'Allamah AlTabātabā' $\bar{\imath}, 352$.

${ }^{31}$ Țabātabā'î, Majmu'at Rasā'il Al- 'Allamah AlTabātabā' $\bar{\imath}, 347$. nilai kebenarannya dengan hal-hal faktual di luar moral dan, di sisi lain, paham non kognitivisme-emotivisme menganggap proposisi moral tidak mungkin diukur nilai kebenarannya, karena tidak termasuk proposisi afirmatif, melainkan hanyalah ekspresi emosional subjek, maka Ṭabātabā' memosisikan proposisi moral sebagai proposisi afirmatif yang dapat dijustifikasi namun tidak memperlakukannya seperti proposisi faktual yang dinilai hukumnya dengan demonstrasi akal sesuai dengan hukum-hukum logika.

Sekilas gagasan Tabāțabā' bersinggungan dengan kognitivisme-naturalis dalam hal kemungkinan justifikasi proposisi moral karena termasuk dalam proposisi afirmatif, namun berbeda dalam hal metodenya. Menurut Tabāțabā'̄̄, justifikasi proposisi moral haruslah dengan tetap mempertimbangkan tindakan moral itu sendiri bukan dengan sesuatu di luar moral (non moral instrumen) sebagaimana klaim kognitivisme-naturalis. Hanya saja, ia menambahkan, proposisi moral tidak dapat dihukum dengan metode demonstrasi (burhān) sesuai dengan kaidah-kaidah logika, melainkan dengan kriteria lain tetapi masih terkait dengan tindakan, yaitu dengan melihat aspek keselarasan (mulā'amah) antara tindakan dan fitrah (tabi'at) pelaku. Suatu tindakan dapat diberi hukum benar bernilai 'baik' jika terjadi keselarasan antara tindakan dan fitrah pelaku (kesempurnaannya) dan, sebaliknya, benar bernilai 'buruk' jika tidak terjadi keselarasan (ghair mulā'amah) antara keduanya, sebagaimana telah dijelaskan. Relasi keniscayaan antar subjek dan predikat dalam proposisi moral tidak dapat dilihat langsung pada makna antara kedua term (subjek dan predikat dalam proposisi), melainkan dari efek yang ditimbulkan oleh 
tindakan bersama dengan tujuan dan fitrah pelakunya. Misalnya, sebagaimana contoh sebelumnya, 'belajar adalah baik', relasi kebenaran predikasi 'baik' bagi subjek 'belajar' tidak didapati secara langsung, tetapi ketika efek 'belajar' dikaitkan dengan tujuan dan fitrah pelaku.

Berangkat dari kriteria penilaian yang didasarkan pada relasi tindakan dengan tujuan dan fitrah pelaku, nilai 'benar-salah' proposisi moral tidak dapat berlaku universal, mengingat setiap individu pelaku memiliki tujuan dan fitrah (tabi'at) yang berbeda-beda. Oleh sebab itu, nilai hukum proposisi moral sangat tergantung pada subjek yang melakukan berikut tujuan dan fitrahnya sendiri yang berbeda dengan pelaku lainnya. Berdasarkan penjelasan ini, nilai hukum proposisi moral dapat dikategorikan bersifat relatif. Țabāțabā'̄i menyebutkan bahwa 'baik' dan 'buruk' merupakan dua sifat I'tibārī (imaginatif) dan relatif yang sangat terkait pada bentuk struktur semangat masyarakat atau pikiran (tabiat) kita. ${ }^{32}$ Dengan kata lain, penyifatan suatu tindakan dengan sifat 'baik' dan 'buruk' tidak bersifat niscaya jika ditinjau dari tindakan sebagaimana tindakan, melainkan sangat terkait, pada tahap berikutnya, dengan tujuan dan tabiat pelaku. Sifat 'baik' dan 'buruk' berlaku tidak tetap dan tidak niscaya, akan tetapi berubah-ubah atau berlaku relatif mengikuti tujuan dan tabiat individu atau masyarakat tertentu. Hal ini pulalah yang semakin menegaskan bahwa sifat baik dan buruk adalah sifat I'tibārī (imaginatif) suatu tindakan.

Dalam hal ini, gagasan relativitas moral Ṭabātabā'̄ tidak sampai pada titik relativisme ekstrim atau disebut juga dengan istilah "meta-etika relativisme" yang menganggap

32 Țabāṭabā'̄̄, Ușūl-i Falsafeh va Ravisye Ri'ālism, 576. bahwa tidak ada satu kaidah moral yang benar atau paling masuk akal, sebaliknya semua kaidah moral yang berbeda secara substansial adalah semuanya benar dan tidak ada yang paling di antara yang lainnya. ${ }^{33}$ Lebih jauh, relativitas moral menurut Ṭabāṭabā'̄ tidak melihat bahwa nilai moral tidak memiliki basis yang objektif melainkan subjektivitas seseorang sehingga menegasikan suatu kebenaran objektif. Ketidak-tetapan dan ketidak-niscayaan sifat 'baik' dan 'buruk' pada suatu tindakan tidak berarti tidak ada kebenaran moral objektif, melainkan kebenaran moral tersebut akan terbukti seiring terpenuhinya syarat, yaitu keselarasan (mulā'amah) antara tindakan, tujuan, dan tabiat pelaku yang mencerminkan keutamaan atau non-keutamaan. Moralitas pada 'belajar adalah baik', misalnya, adalah benar dan akan selalu demikian selama berkesesuaian dengan tujuan dan tabiat pelaku yang memang menuntut penyifatan dengan sifat 'baik'. Jadi relativitas moral dalam meta-etika Ṭabāțabā' $\overline{1}$ tidak dalam makna bahwa tidak ada satu kebenaran moral dan setiap orang tidak bisa menghukumi moral orang lain, karena semuanya benar sesuai dengan subjektivitas masing-masing, sebagaimana klaim relativisme ekstrim dalam meta-etika. ${ }^{34}$

2. Ontologi Moral: Eksistensi Moral dalam Tiga Serangkai Komponen

Sebagai seorang filsuf realis, tidak terkecuali dalam moralitas dan etika, Ṭabātabā'̄i meyakini bahwa nilai moral memiliki objektivitas dan bukan sekedar kreasi subjektif mental. Namun demikian,

33 Mohammad A. Șomali, Ethical Relativism: An Analysis of the Foundations of Morality, diterjemahkan oleh Zaimul Am, (Jakarta: Sadra Press, 2011), 50-51.

34 Piers Benn, Ethics, (London: UCL Press, 1998), 18. 
menurutnya, eksistensi nilai moral tidak semata terdapat pada tindakan sebagaimana tindakan atau tindakan an sich, karena jika demikian nilai moral pada setiap tindakan tidak akan berbeda-beda bagi semua orang. Misalnya, tindakan 'memukul' niscaya akan bernilai buruk bagi siapa pun, meskipun bagi orang tertentu akan menganggapnya baik ketika itu dilakukan untuk mempertahankan diri saat ia dianiaya orang lain. Hal ini, menurut Țabāṭabā'̄̄, menunjukkan bahwa nilai moral tidak bersumber langsung dari tindakan sebagai sifat esensialnya, "buruk" bukanlah sifat esensial bagi "memukul" sehingga berlaku niscaya dan tetap pada semua tindakan 'memukul' dan oleh siapa pun. ${ }^{35}$ Selain itu, hal ini tidak pula berarti bahwa tindakan tidak memiliki nilai sama sekali, sebagaimana nihilisme yakini, sehingga mental tidak menangkap apa pun darinya dan nilai moral hanyalah ekspresi dari emosi pelaku atau orang lain, sebagaimana klaim emotivisme. Sebaliknya, setiap tindakan tetap memiliki nilai yang selalu menjadi pertimbangan bagi seseorang untuk melakukan atau tidak. Nilai tersebut berada pada tindakan bersama dengan tabiat pelaku dan tujuan atau kebutuhan hidupnya. Ketiga rangkaian komponen tersebut merupakan sumber dari nilai moral berupa nilai keutamaan atau sebaliknya yang kemudian menjadi objek bagi mental untuk memersepsi konsep 'baik' dan 'buruk' dan menyifati suatu tindakan dengannya.

Berdasarkan penjelasan di atas, sifat esensial tindakan ketika dikaitkan dengan tabiat dan tujuan pelaku adalah keutamaan sehingga tindakan tersebut harus dilakukan atau, sebaliknya, tidak utama (membawa kepada ketidaksempurnaan) sehingga

35 Ṭabāṭabā'î, Majmu'at Rasā'il al- 'Allamah alTabātabā', 352. tindakan tersebut harus ditinggalkan atau tidak harus dilakukan. Dari sifat esensial keutamaan dan ketidakutamaan, harus dan tidak harus dilakukannya suatu tindakan bersama tujuan dan tabiat pelaku inilah kemudian mental menyifatkan konsep I'tibārī 'baik' dan 'buruk'. Sifat 'baik' dan 'buruk' memang tidak dicerap secara langsung dari suatu tindakan, namun penyifatannya tetap memiliki alasan atau konteks (qarinah), keutamaan atau tidak dan harus atau tidak harus, dengan realitas hakiki yaitu tindakan. Dengan kata lain, keutamaan (awlawiyat) atau ketidakutamaan (ghair awlawiyat) merupakan alasan bagi keputusan harus (yanbaghi) atau tidak harus (lā yanbaghi) dilakukannya suatu tindakan. Selanjutnya, harus dan tidak harus adalah alasan bagi mental untuk menyebut suatu tindakan 'baik' atau 'buruk'; sifat 'harus' meniscayakan mental untuk menyebut suatu tindakan sebagai 'baik' dan sifat 'tidak harus' meniscayakan mental untuk menyebut 'buruk' tindakan tersebut. Hal ini sebagaimana ditegaskan oleh Tabātabā' bahwa pertimbangan keharusan melakukan suatu tindakan merupakan keniscayaan bagi penyifatan sifat baik oleh mental terhadap tindakan tersebut dan, sebaliknya, pertimbangan ketidakharusan untuk melakukan suatu tindakan adalah keniscayaan bagi mental untuk menyifati secara I'tibārī sifat buruk terhadap tindakan. ${ }^{36}$

Rangkaian tindakan bersama dengan tujuan dan tabiat pelaku bukanlah objek sesungguhnya (hakiki) bagi konsep 'baik' dan 'buruk', sebab keduanya bukanlah makna yang dapat diaplikasikan atau dikorespondensikan secara hakiki terhadap tiga serangkai tersebut. Konsep 'baik' dan 'buruk' dicerap dan disifatkan mental secara

36 Ṭabāṭabā'̂̂, Majmu'at Rasā' 'il Al- 'Allamah AlThabāthab̄', $i, 353$. 
I'tibārì dengan tetap berangkat dari pertimbangan tiga serangkai tersebut. Jadi, fungsi tiga serangkai tersebut adalah materi/bahan pertimbangan dan sumber yang di dalamnya terdapat alasan kesesuaian penyifatan, bukan objek yang dipresentasikan secara langsung sebagaimana persepsi hakiki. Meski demikian, bukan berarti nilai moral bersifat subjektif dan ilusif, melainkan riil dan objektif yang terjaga oleh ketiga rangkaian antara tindakan, tujuan dan tabiat pelaku.

\section{Simpulan}

Investigasi dan analisis terhadap teori I'tibāriyat 'Allamah Tabāṭabā'̄ yang memperlihatkan salah satu jenis konsep I'tibāri berupa konsep moral, 'baik' dan 'buruk' merefleksikan suatu bentuk metaetika yang unik. Secara sekilas gagasan Tabātabā'̄i ini, di satu sisi, mengafirmasi beberapa aliran meta-etika modern seperti Naturalisme moral dan Emotivisme moral dari sudut pandang masing-masing, namun, di sisi lain, berbeda jauh dengan keduanya. Meta-etika Tabātabā'̄ berangkat pada poin yang sama dengan Naturalisme bahwa moralitas dapat dijustifikasi, namun berbeda dengan klaim Naturalisme bahwa moralitas diperlakukan seperti benda-benda faktual, "nilai adalah fakta", dan dihukum dengan sesuatu di luar moral, melainkan moralitas harus perlakukan sebagai nilai yang ada pada tindakan atau moral dan dihukum dengan realitas tindakan itu sendiri. Hal ini ditegaskan dalam teori I'tibāriyat bahwa nilai moral secara objektif terdapat dalam tindakan yang terangkai dengan tujuan dan tabiat pelaku yang melahirkan sifat keutamaan (awlawiyah) atau kontra-keutamaan (ghair awlawiyah) dan darinyalah mental secara kreatif memersepsi secara tidak langsung konsep 'baik' dan 'buruk'. Meta-etika
Ṭabāțabā'̄ juga bersinggungan dengan Emotivisme dalam hal bawa tindakan pada dirinya sendiri (action an sich) adalah netral, tidak ada nilai baik dan buruk, atau 'baik' dan 'buruk' bukanlah sifat esensial yang dapat dicerap secara langsung, namun berbeda dengan Emotivisme yang mengklaim moralitas hanyalah ekspresi dari luapan emosi seseorang, melainkan realitas objektif yang ada pada tindakan bersama dengan tujuan dan tabiat pelaku. Hal ini menegaskan pula, di saat yang bersamaan, bentuk realisme moral yang dianut oleh Tabātabā'̄̄.

Selain itu, keunikan meta-etika Tabātabā'̄̄ berdasarkan teori I'tibāriyat adalah menekankan pada relativisme moral meskipun bukan dengan makna ekstrem yang menentang adanya kebenaran objektif moral. Hal ini ditunjukkan dalam prinsip bahwa penyifatan sifat 'baik' dan 'buruk' oleh mental terhadap tindakan sangat terkait dengan tujuan dan tabiat individu dan kelompok pelaku tertentu yang berbeda dengan individu dan kelompok lain. Berangkat dari keunikan-keunikan meta-etis tersebut berdasarkan teori I'tibāriyat, dua hal menyangkut moralitas dapat direfleksikan, yaitu: status epistemologis moral adalah Imaginatif-Relatif-Kognitif dan status ontologis moral adalah Eksistensi Moral dalam Tiga Serangkai Komponen. Kedua bentuk refleksi ini dalam elaborasinya sekaligus merupakan respons terhadap klaimklaim meta-etika, khususnya dari Naturalisme moral dan Emotivisme moral yang bersifat Anti-Realis.

\section{Pustaka Acuan}

Amal, Taufik Adnan dan Panggabean, Syamsurizal. Tafsir Kontekstual AlQur'an, Bandung: Mizan, 1989. 
Baljon, J.M.S. Modem Muslim Koran Interpretation, Leiden E J Brill, 1968.

Benn, Piers. Ethics, London: UCL Press, 1998.

Baqirshani, Ali Naqi, "Dasar-dasar Nilai Moral Studi Komparatif atas Pandangan Allamah Thabathaba'i dan Ayatullah Muthahhari", Al-Huda: Jurnal Kajian ilmu-ilmu Islam, Vol. 1, No. 2. 2000.

Baqir, Haidar (peny), S H Nasr, "Tentang Penulis", dalam Thabathaba'i, Hikmah Islam, Bandung: Mizan, 1993.

Fisher, Andrew. Metaethics: An Introduction. UK: Acumen Publishing, 2011.

Frankena. William K. Ethics. USA: PrenticeHall International Inc, 1973.

Gray, James W. A Free Introduction to Moral Philosophy, 2010.

Haleem, Muhammad Abdul. Understanding the Qur'anic Themes and Style, New York: I.B Tauris Publisher, 1999.

Hamdani, Basrir. Modus Realisme Berdasarkan Teori Persepsi I'tibāriyat Tabātabā'̄i. Disertasi program Doktoral pada al-Mustafa International University - Iran yang telah disidangkan pada 29 Maret, 2016.

Hasan Mu'allimi, Dkk. Tārīkh Falsafeh Islāmī. Qom: Markaz Jahāni 'Ulūm Islāmī, 1385 H.

Husein, Fatimah. Fazlur Rahman's Islamic Philosophy, Metreal: Institute of Islamic Studies McGill University, Tesis, 1997.

Irawan, Bambang. "Pemikiran Epistemologi Țabāṭabā'î”, Teologia: Jurnal Ilmu-ilmu UShuluddin, Vol. 25, No. 1, Semarang: Fakultas Ushuluddin IAIN Walisongo, 2014.
Miller, Alexander. An Introduction to Contemporary Metaethics. UK: Polity Press, 2003.

. "Non-Cognitivism." In The Routledge Companion to Ethics, edited by John Skorupsi. USA: Routledge, 2010.

Nasr, Sayyid Hosen. "Sang Alim dari Tabriz", dalam Thabathaba'i", Menyingkap Rahasia Al-Qur'an, terj. A Malik Madaniy dan Hamim Ilyas, Bandung Mizan, 1993.

Perry, R. B. Realms of Value. Cambridge: Harvard University Press, 1954.

Pigden, Charles R. "Naturalism." In $A$ Companion to Ethics, edited by Peter Singer. UK: Blackwell Publisher Ltd, 1993.

Shomali, Mohammad A. Ethical Relativism: An Analysis of the Foundations of Morality, terj. Zaimul Am. Jakarta: Sadra Press, 2011.

Ṭabātạā̄'̄i, Muḥammad Husein. Nihāyat AlHikmah. Qom: Mu'assese-i Āmuzesy-i va Phezuhesy-i Imām Khumeini, 1390 $\mathrm{H}$.

Bidāyat Al-Hikmah, Qum: Muassasah An-Nasyr Al-Islami, $1422 \mathrm{H}$.

-------. Usūul-i Falsafeh va Ravisye Ri'ālism. Iraq: al-Mu'assasah al-'Iraqiyah, 1418 $\mathrm{H}$.

-------. Majmū'at Rasā'il Al-Allamah AlTabātabā'ì. Qom: Maktabah Fadak, 2007.

------. "Hidupku" dalam, Inilah Islam: Upaya Memahami seluruh Konsep Islam secara Mudah, Bandung: Pustaka Hidayah, 1996.

Yazdi, M. Taqi Miṣbaḥ. Al-Manhāj Al-Jadīd 
36 Ilmu Ushuluddin, Volume 7, Nomor 1, Januari 2020

Fi Ta'lìm Al-Falsafah. Beirut: Dār alTa'aruf wa al-Mațū' at, 1998.

Yazdi, Mahd̄̄ Ḥāirī. The Principles of Epistemology in Islamic Philosophy: Knowledge by Presence, New York: State University of New York Press, 1992.

------. Epistemologi Iluminasionis dalam Filsafat Islam: Menghadirkan Cahaya Tuhan, terj. Ahsin Muhammad, Bandung: Mizan, 2003. 